\title{
An In vitro Approach for Evaluating Antimicrobial Activity and Production of Kojic Acid by Aspergillus flavus Isolated from Karwar Region
}

\section{G. Sanjotha ${ }^{1}$ (D) C.T. Shivasharana ${ }^{1 *}$ (1) and Sudheer I. Manawadi ${ }^{2}$ (D)}

${ }^{1}$ PG Studies in Biotechnology and Microbiology, Karnataka University, Dharwad, India. ${ }^{2}$ Department of Biotechnology, Government Arts and Science College, Karwar, India.

\begin{abstract}
Biosynthesis of kojic acid by fungi has been acquired huge attention nowadays because it can be used as an alternative method to chemically synthesized compounds. The fundamental feature of the microbiological agitation practice was to obtain potential fungi to achieve greater amount of kojic acid, the fungal isolate used in this study exhibited maximum growth on PDA and was identified as A.flavus based on its microscopic and macroscopic characteristics and ITS sequence analysis. In this vignette, appropriate cultivation conditions were carried out to gain a highest quantity of kojic acid. The maximum yield of kojic acid $(31 \mathrm{~g} / \mathrm{l})$ was reached by formulating the medium. The massive amount of kojic acid and maximum biomass was achieved from $A$. flavus by utilizing yeast extract as a nitrogen source and carbon source as glucose. The optimum incubation temperature employed was at $30^{\circ} \mathrm{C}$, optimal $\mathrm{pH}$ was 3. Antagonistic activity was analyzed against both bacterial and fungal pathogens. The ethyl acetate extract exhibit increased antibacterial activity and maximum antifungal activity comparable with methanol, and chloroform.
\end{abstract}

Keywords: Aspergillus flavus, kojic acid, antimicrobial activity, optimization, dry biomass.

*Correspondence: shivaskud@gmail.com

(Received: 23 September 2019; accepted: 30 November 2019)

Citation: G. Sanjotha, C.T. Shivasharana and Sudheer I. Manawadi, An In vitro Approach for Evaluating Antimicrobial Activity and Production of Kojic Acid by Aspergillus flavus Isolated from Karwar Region, J Pure Appl Microbiol., 2019; 13(4):2261-2272 https://doi.org/10.22207/JPAM.13.4.40

(C) The Author(s) 2019. Open Access. This article is distributed under the terms of the Creative Commons Attribution 4.0 International License which permits unrestricted use, sharing, distribution, and reproduction in any medium, provided you give appropriate credit to the original author(s) and the source, provide a link to the Creative Commons license, and indicate if changes were made. 


\section{INTRODUCTION}

Throughout evolution, an attempt was made to include marine microbes into the area of the pharmaceutical industry to discover new drugs $^{1}$. Fungal isolates obtained from marine habitats have been identified as renowned producers of unique bioactive compounds ${ }^{2}$. Various Species of the genera Aspergillus have known repositories of antimicrobial substances with the highest efficiency ${ }^{3}$. The global health care system is facing the problem of multi-resistant microbes $^{4-6}$. Most of the bacterial species exhibit antagonistic properties towards various antibiotics. In recent years, the majority of bacterial isolates such as $S$. aureus are exhibiting resistance mechanisms against ciprofloxacin, erythromycin, clindamycin ${ }^{7-10}$, Escherichia coli, Pseudomonas spp. and Klebsiella spp were involved in drugresistant bacterial septicemia in Ile-Ife, Nigeria ${ }^{10}$. In the living cells, the chemical synthesis of kojic acid develops free radicals ${ }^{11}$. To overcome this consequence, several attempts have been made to choose a different approach to produce kojic acid. Recent investigations have concentrated on the isolation and usage of kojic acid from microorganisms as another non-toxic and secure method. In industry, biosynthesis of kojic acid from Aspergillus species is treated as one of the finest approaches ${ }^{12}$. More than 58 various species like Aspergillus, Penicillium, Mucor, etc, are used for Production of kojic acid ${ }^{13}$.

As far as the advancement of the potentiality of fungi to produce a considerable number of biologically active secondary metabolites that are involved in enhancement of ecological strength, and most of them perform the significant role as agents in defense mechanism, advancing regulators, insect attractants and as an agent for communicating with other organisms ${ }^{14}$. These pharmacologically active substances exhibit various properties such as antimicrobial, antitumor, antihyper-cholesterolemic, and Immunosuppressant ${ }^{15-19}$.

Additionally endophytic fungi are also renowned for the synthesis of similar bioactive metabolites from plants like Catharanthus alkaloids that are produced by endophytic fungi such as campthothecin, vinblastine, vincristine and, paclitaxel these are potent drugs for cancer ${ }^{20}$,
In such a way endophytic fungi Aspergillus flavus influence prominent role in finding novel bioactive metabolites and they require very small quantity of substance from plants. In some tropical areas, maximum exposure of skin to sunlight can result in an elevated risk that leads to skin cancer, oxidative stress, and sunburn ${ }^{21}$. To prevent the hazardous cause of ultraviolet rays, kojic acid isolated from fungi has been used in many cosmetic creams, lotions, and soaps because they prevent hyperpigmentation and tyrosinase inactivity, it is also used to avoid food browning 22 .

Hence kojic acid and its derivatives have developed huge applications in medicine, Pharmaceutical industries, agricultural, chemical and food industries ${ }^{22}$. Along with kojic acid, its derivatives are also found to enhance solidity and solubilizing nature of kojic acid in various oily creams in the cosmetic industry ${ }^{23-26}$. Further other derivatives of kojic acid can have the capacity to inhibit tyrosinase activity and it has 8 times deeper potentiality than kojic acid ${ }^{24}$.

Some earlier reports have described as flufuran (5-(hydroxymethyl)-furan-3-carboxylic acid) is an isomer of kojic acid but recent studies indicates that flufuran was misidentified ${ }^{27}$.

Kojic acid (5-hydroxy-2-hydroxymethylgamma- pyrone; KA) is synthesized from different microbes like fungi and some bacteria ${ }^{28,29}$. In the group of Aspergillus species, the oryzaeflavus- tamarii category is considered as the highest producer of kojic acid ${ }^{30}$. It is an essential secondary metabolite mainly obtained from carbohydrates. Kojic acid has wide applications in the medical field as an anti-inflammatory drug, it has been used as a pain killer, in the food industry it is utilized as an anti-speck, as a flavor enhancer, and in traditional foods, it gives special taste and color ${ }^{31,73}$. The purpose of usage of kojic acid in the agriculture field is that it acts as an anti-melanosis of agriculture products by preventing polyphenol oxidase formation ${ }^{32}$. Kojic acid exhibits bio-pesticide and bio- fungicidal activities in agriculture. In the agriculture field, it has been preferred for its biodegradable activity. It has various biological activities such as antibacterial, antifungal, antioxidant. It is also used as a whitening agent in the cosmetic industry ${ }^{33}$. Various microorganisms produce kojic acid as 
azidometalkojates form that exhibits antimicrobial activity. Besides, it acts as a chelating agent in insecticides production ${ }^{34,35}$.

Different carbon, nitrogen sources, $\mathrm{pH}$ and temperature can be employed for an adequate amount of kojic acid production. Until now, an ample amount of kojic acid has been obtained with the glucose that was used as a carbon source. Most of the Aspergillus and Penicillium species are potent producers of Kojic acid $^{36}$. Among Aspergillus species, Aspergillus flavus being attentive as the maximum producer of Kojic acid. Therefore the present survey was carried out to isolate and explore the antagonistic activity of biologically active compounds obtained from Aspergillus flavus and the results achieved were used to progress the control cultural strategy to produce maximum kojic acid.

\section{MATERIALS AND METHODS \\ Obtaining the fungi and its extracts}

Soil samples were gathered from different regions in and around the coastal area of Karwar, Karnataka, India, during winter and summer seasons. Each sample was placed in sterilized tightly sealed polythene bags and brought to the laboratory for further investigation. Fungal isolates were separated by employing a serial dilution method on PDA medium supplemented with chloramphenicol $(50 \mathrm{ppm})$ to retard the growth of bacteria, incubated at $28^{\circ} \mathrm{C}$ at $\mathrm{pH} 6$, for seven days, isolated colonies were grown separately.

Isolate that showed better growth was identified by using slide culture technique and lactophenol cotton blue staining technique and it was identified based on their morphological characteristics. Molecular characterization was carried out. Chromosomal DNA was extracted by using a spin column kit (Hi-Media, India or similar manufacturers. Fungal ITSrRNA gene (600 bp) ${ }^{37}$ amplification was carried out by using a PCR method in a thermal cycler and were purified using Exonuclease I - Shrimp Alkaline Phosphatase $\left(\right.$ Exo-SAP) ${ }^{38}$. Sanger method in ABI 3500xl genetic analyzer (Life Technologies, USA) was used to sequence purified amplicons. Sequencing files (.ab1) rearranged using CHROMASLITE (version 1.5) and further evaluated by Basic Local Alignment Search Tool (BLAST) with adjacent culture sequence recovered from the National Centre for Biotechnology Information (NCBI) database that locates a range of local analogy among sequences ${ }^{39}$. The program correlates protein or nucleotide sequences to database sequences and determines the statistical implication of similarities ${ }^{40}$. The BLAST algorithms deployed to interpret practical and progressive correlation among the sequences and it also helps to relate members of gene families. (i) Fundamental examination to search probably closely linked type strain sequences using the BLASTN program22 (ii) Pairwise arrangement to enumerate the sequence analogy values within the query sequence and the sequences identified in step (i ${ }^{41}$. Therefore, each isolate is reported with the first five-ten hits observed in the said database. And the strain was identified and confirmed as Aspergillus flavus. Therefore further studies were conducted by employing A.flavus for the extraction of bioactive compounds.

\section{Production of kojic acid}

The sterile $70 \mathrm{ml}$ medium in $250 \mathrm{ml}$ Erlenmeyer flask employed for kojic acid production from $1 \mathrm{ml}$ of stock solution of $A$. flavus, ( 1 x 108 spore per $\mathrm{ml}$ ) consisting of glucose (100 g/l); $\mathrm{NaNO}_{3}(2 \mathrm{~g} / \mathrm{l}) ; \mathrm{KH}_{2} \mathrm{PO}_{4}(1 \mathrm{~g} / \mathrm{l}) ; \mathrm{MgSO}_{4} \cdot 7 \mathrm{H}_{2} \mathrm{O}(0.5 \mathrm{~g} / \mathrm{l})$; $\mathrm{KCl}(0.5 \mathrm{~g} / \mathrm{l})$; and $\mathrm{FeSO}_{4} \cdot 7 \mathrm{H}_{2} \mathrm{O}(0.01 \mathrm{~g} / \mathrm{l})$. The culture was incubated at $30^{\circ} \mathrm{C}, 150 \mathrm{rpm}$ in incubator shaker for 30 days. Mycelium was separated by filtering through layers of sterile muslin cloth and then centrifuged at $6000 \mathrm{rpm}$ for $15 \mathrm{~min}$. Later Filtrate was transferred to the separating funnel containing ethyl acetate, chloroform, methanol (1:1 ratio) separately, aqueous and organic layers were separated followed by evaporation in a rotary evaporator. Kojic acid crystals were obtained by evaporation, these crystals were weighed and then placed in a clean vial ${ }^{42}$. Kojic acid concentration was determined against blank (the filtrate collected from the medium that is not inoculated) all the observations were used in triplicates.

\section{Analytical determination of kojic acid and glucose}

The analytical determination of glucose concentration was carried out by the DNS method $^{43}$. Dinitrosalicyclic acid (DNS) reagent consisting of 3,5- dinitrosalicylic acid (10 g/l), phenol $(2 \mathrm{~g} / \mathrm{l})$, sodium sulfite $(5 \mathrm{~g} / \mathrm{I})$ and $\mathrm{NaOH}$ $(10 \mathrm{~g} / \mathrm{l})$ was developed and $1 \mathrm{ml}$ of DNS reagent was added to $1 \mathrm{ml}$ of supernatant, boiled for $10 \mathrm{~min}$ in boiling water bath, then it was cooled 
and $1 \mathrm{ml}$ of Rochelle salt was supplemented. The spectrophotometer was used to measure the absorbance at $575 \mathrm{~nm}$.

The determination of the quantity of kojic acid was performed by a colorimetric method ${ }^{44}$. The experiment was conducted by mixing $1 \mathrm{ml}$ of supernatant with $1 \mathrm{ml}$ of ferric chloride $\left(\mathrm{FeCl}_{3}\right)$ solution, which was prepared by placing $\mathrm{FeCl}_{3} \cdot 6 \mathrm{H}_{2} \mathrm{O}$ $(1 \mathrm{gm})$ in $100 \mathrm{ml}$ of $\mathrm{HCl}(0.1 \mathrm{~N})$. The reddish color was formed due to the reaction between hydroxyl and phenolic functional groups present in the samples. The absorbance of the sample was estimated at $500 \mathrm{~nm}$ by employing a spectrophotometer and used the kojic acid standard curve to determine the kojic acid equivalent.

\section{Screening of antimicrobial activity}

The extract obtained from the isolate was bioassayed for antibacterial and antifungal activity, this was analyzed by agar-based disk diffusion method ${ }^{45}$, against two gram-negative and two gram-positive bacteria and one fungal isolate. $0.2 \mathrm{ml}$ of an overnight grown culture of target bacteria were inoculated on Nutrient agar medium, in similar fashion $0.2 \mathrm{ml}$ of cultured target fungal isolate was on sabouraud's agar medium. By using sterile spreader the two cultures were evenly spread out. A constant amount of $20 \mu \mathrm{l}$ of the extract of the isolate was applied on the sterile Whatman antibiotic assay discs of $6 \mathrm{~mm}$ diameter later located over the surface of the agar medium. Bacterial cultures were incubated at $37^{\circ} \mathrm{C}$ for $24 \mathrm{~h}$ and fungal plates at $25^{\circ} \mathrm{C}$ for $72 \mathrm{~h}$. Diameters of inhibition zones were recorded. The analysis was achieved in duplicate.

\section{Estimation of the dry weight of fungi}

To determine the dry weight of the isolate the culture broth was drained through the sterile filter paper (Whatman 1). The mycelium was washed. The weight of the empty filter paper was measured, later weight was measured along with the fungal mycelium and then filter paper along with mycelium was placed in the oven at $95^{\circ} \mathrm{C}$ until the stable weight was reached, subsequently fungal dry biomass was measured ${ }^{46}$.

\section{Analyzing the effect of nutritional conditions on} kojic acid production

Different aspects were employed for the increased production of kojic acid. These aspects comprised:

\section{The response of carbon source}

Different kinds of carbon sources such as glucose, fructose, maltose, lactose, sucrose, starch, cellulose, xylose, arabinose were employed in the final concentration of carbon remained same $(100 \mathrm{~g} / \mathrm{l})$ in the medium, $\mathrm{pH}$ of the cultures were adjusted, were sterilized and incubated for 13 days in order to determine the prominence of carbon on kojic acid biosynthesis and increase of fungal biomass by measuring dry weight of mycelia. Analysis of kojic acid and the level of glucose was performed by colorimetric method $^{44}$. A. flavus utilize glucose as the prime source to manufacture a maximum quantity of kojic acid ${ }^{47}$. Glucose that acquired during the agitation process converts into kojic acid by the action of various enzymes associated with cell ${ }^{48,49}$ such as hexokinase and gluconate dehydrogenase, glucose-6-phosphate dehydrogenase, glucose is considered as the finest precursor for the maximum kojic acid synthesis.

The response of nitrogen source

The response of prominent nitrogen on kojic acid formation as well as increased biomass was determined by using different nitrogen sources such as ammonium nitrate, ammonium dihydrogen phosphate, ammonium mono hydrogen phosphate, yeast extract, asparagine, sodium nitrate, potassium nitrate at $0.2 \% \mathrm{w} / \mathrm{v}$ concentration was used.

\section{The response of incubation temperature}

Temperature plays a vitalizing role in the greatest recovery of kojic acid and the maximum yield of biomass. Different ranges of temperature $15,20,25,30,35,40,45^{\circ} \mathrm{C}$ were studied to understand the effect of temperature.

\section{The Response of $\mathrm{pH}$}

The fermentation medium was adjusted to various $\mathrm{pH}$ ranging from $2,3,4,5,6,7,8$ to examine the consequence of an action of $\mathrm{pH}$ on the improvement of kojic acid biosynthesis and dry mass.

\section{RESULTS AND DISCUSSION \\ Microscopic observation and molecular characterization \\ Macroscopic, microscopic study (Fig. 1 and 2) and molecular identification revealed that the fungal isolate was belonging to the}


genus Aspergillus and it is confirmed that isolate was $A$. flavus. The Genbank Accession number is MK521427.

\section{Recovery of kojic acid and the estimation of biomass}

The A.flavus was isolated for its potentiality to manufacture the highest kojic acid first on the PDA medium and then it was cultured on the production medium [glucose $(100 \mathrm{~g} / \mathrm{l})$; $\mathrm{NaNO}_{3}(2 \mathrm{~g} / \mathrm{l}) ; \mathrm{KH}_{2} \mathrm{PO}_{4}(1 \mathrm{~g} / \mathrm{l}) ; \mathrm{MgSO}_{4} \cdot 7 \mathrm{H}_{2} \mathrm{O}(0.5$ $\mathrm{g} / \mathrm{l}) ; \mathrm{KCl}(0.5 \mathrm{~g} / \mathrm{l}) ;$ and $\mathrm{FeSO}_{4} \cdot 7 \mathrm{H}_{2} \mathrm{O}(0.01 \mathrm{~g} / \mathrm{l})$.] at $28 \pm 2^{\circ} \mathrm{C}$. Kojic acid was extracted with ethyl acetate, chloroform and methanol (1:1 ratio), aqueous and organic layers were separated, evaporated in a rotary evaporator to acquire maximum $24.1 \mathrm{~g} / \mathrm{I}$ of kojic acid and increased dry weight $8.2 \mathrm{~g} / \mathrm{l}$ with ethyl acetate extract, while kojic acid and dry mass from methanol extract was $20.4 \mathrm{~g} / \mathrm{l}$ and $7 \mathrm{~g} / \mathrm{l}$, and from chloroform extract $14.3 \mathrm{~g} / \mathrm{I}$ and $6.5 \mathrm{~g} / \mathrm{I}$ was achieved. Hence ample amount of kojic acid and dry mass were obtained with ethyl acetate extract as the fermentation process progressed up to 13 days. Such type of performance of kojic acid biosynthesis and dry mass by A.flavus was reported ${ }^{50-56}$.

Previous studies described that several species and strains of Aspergillus genus such as $A$. flavus, $A$. oryzae and $A$. parasiticus $s^{57-66}$ are potent producers of kojic acid. Some earlier results showed that $A$. flavus strain 44-1 acquire 32.50 $\mathrm{g} / \mathrm{l}$ of kojic acid by employing rotary shaker ${ }^{66}$. Our results were comparable with reporter ${ }^{67}$ who demonstrated that an increased amount of kojic acid $39.9 \mathrm{~g} / \mathrm{I}$ was obtained by $A$. flavus strain 44-1 by applying SMF. Contrarily, a minimum level of kojic acid production $20 \mathrm{~g} / \mathrm{l}$ by $A$. oryzae NRRL 484 in shake flask culture was reported ${ }^{68}$. However, the kojic acid biosynthesis by $A$. oryzae NRRL 484 was recorded $^{28}$ as $24 \mathrm{~g} / \mathrm{l}$. After the recovery of kojic acid, it was estimated quantitatively by using the standard method ${ }^{44}$. The highest amount of kojic acid $24.1 \mathrm{~g} / \mathrm{l}$ was attained by ethyl acetate extract

Table 1. Characteristics of $A$. flavus

\begin{tabular}{ll}
\hline Criteria & Characteristics \\
\hline Macroscopic observation & $\begin{array}{l}\text { Colony on PDA media, after seven days of incubation at } 28 \pm 2{ }^{\circ} \mathrm{C} \\
\text { shows } 46 \mathrm{~mm} \text { in diameter. Velvety, yellow to green or dark green, } \\
\text { Reverse hyaline, goldish to red brown. } \\
\text { Microscopic observation }\end{array}$ \\
$\begin{array}{l}\text { Conidial heads are radiate and conidiophores are uncolored and } \\
\text { Varying in length, commonly rough, hollow, and spiny in nature. } \\
\text { of phialides }\end{array}$ & $\begin{array}{l}\text { Both Uni-seriate and bi-seriate, whole vesicle is covered with } \\
\text { phialides, extend in all directions }\end{array}$
\end{tabular}



Fig. 1. Macroscopic examination of $A$. flavus

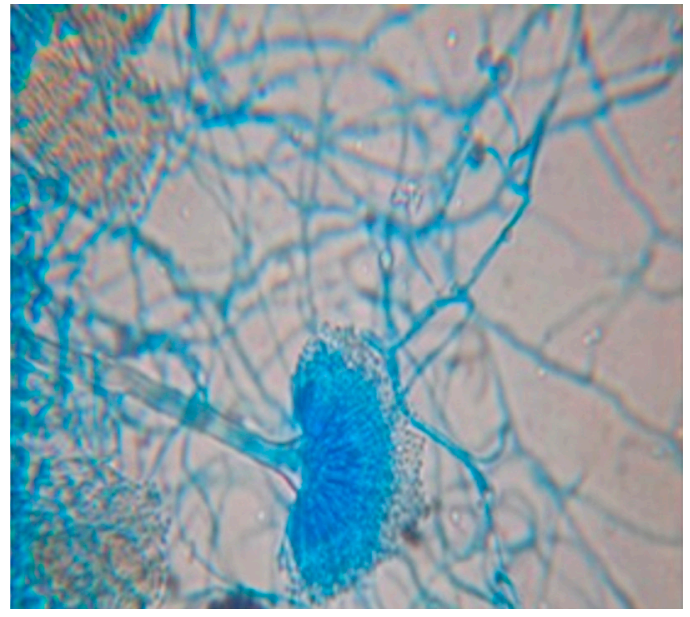

Fig. 2. Microscopic examination of $A$. flavus 
Table 2. Extraction solvents for the biosynthesis of kojic acid and dry mass by $A$. flavus

\begin{tabular}{lcc}
\hline $\begin{array}{l}\text { Extraction } \\
\text { Solvents }\end{array}$ & $\begin{array}{c}\text { Kojic acid } \\
(\mathrm{g} / \mathrm{l})\end{array}$ & $\begin{array}{c}\text { Dry mass } \\
(\mathrm{g} / \mathrm{l})\end{array}$ \\
\hline Ethyl acetate & 24.1 & 8.2 \\
Methanol & 20.4 & 7.0 \\
Chloroform & 14.3 & 6.5 \\
\hline
\end{tabular}

by A.flavus when compared to methanol extract and from chloroform extract as shown in (Table 2). The vignette explores that the greatest quantity of kojic acid was synthesized by $A$. flavus whereas Aspergillus tamarii produces less quantity of kojic $\operatorname{acid}^{49}(15.2 \mathrm{~g} / \mathrm{l})$.

\section{Antagonistic property of $A$. flavus}

Kirbey-Bauer antibiotic testing (Agar based disk diffusion) method was carried out to test the antagonistic activity of the isolate against E. coli (MTCC 1687), P. aeroginosa (MTCC 1688), S. aureus (MTCC 96), B. subtillis (MTCC 441), A.flavus exhibit maximum zone of inhibition with crude ethyl acetate extract when compared to methanol extract and chloroform extract showed minimum zone of inhibition and chloramphenicol was used as control (Table 1). Antifungal activity by the isolate was conducted against $C$. albicans that was comparable with fluconazole as a standard antibiotic (Table 2). The diameter of the zone of inhibition was measured and was taken as a sensitivity test of bacteria and fungi.

\section{Optimization conditions on kojic acid production} by $A$. flavus

The kojic acid production by $A$. flavus was achieved by optimizing cultural conditions like carbon source, nitrogen source, incubation temperature and $\mathrm{pH}$ of the medium. To test the effect of carbon sources on the formulation of kojic acid and mycelia, different carbon sources were supplemented separately to the medium in constant concentration $(100 \mathrm{~g} / \mathrm{l})$. The outcome of the present work showed in (Table 5) indicates that the perfect carbon source for synthesis of kojic acid with dry mass was glucose $(30.1 \mathrm{~g} / \mathrm{l})$ and $(8.2 \mathrm{~g} / \mathrm{l})$ subsequently sucrose, fructose, lactose $(28.3,25.2$, $18.4 \mathrm{~g} / \mathrm{l}$ respectively) (8, 7.6, $7.5 \mathrm{~g} / \mathrm{l}$ respectively). According to some workers ${ }^{49,70,59}$, the structure of glucose is almost identical to kojic acid, during the

Table 3. Bioactivity of crude extracts of A.flavus against four bacterial pathogens

\begin{tabular}{lccccc}
\hline \multirow{5}{*}{ Solvents } & \multicolumn{5}{c}{ Zone of inhibition in $\mathrm{mm}$} \\
\cline { 2 - 6 } & $\begin{array}{c}\mathrm{Ec} \\
1 \mathrm{mg} / \mathrm{ml}\end{array}$ & $\begin{array}{c}\mathrm{Pa} \\
1 \mathrm{mg} / \mathrm{ml}\end{array}$ & $\begin{array}{c}\text { Sa } \\
1 \mathrm{mg} / \mathrm{ml}\end{array}$ & $\begin{array}{c}\mathrm{Bs} \\
1 \mathrm{mg} / \mathrm{ml}\end{array}$ & $\begin{array}{c}\mathrm{Ch} \\
1 \mathrm{mg} / \mathrm{ml}\end{array}$ \\
\hline Ethyl acetate & $20 \pm 0.1$ & $19 \pm 0.2$ & $20 \pm 0.1$ & $21 \pm 0.7$ & $23 \pm 0.7$ \\
Methanol & $16 \pm 0.5$ & $14 \pm 0.8$ & $17 \pm 0.3$ & $18 \pm 0.1$ & $22 \pm 0.4$ \\
Chloroform & $13 \pm 0.4$ & $15 \pm 0.3$ & $12 \pm 0.6$ & $15 \pm 0.8$ & $21 \pm 0.2$ \\
\hline
\end{tabular}

The zone of inhibition of each extracts were expressed as the mean \pm standard deviation. Ec- Escherichia coli, Pa- Pseudomonas aeruginosa, Sa-Staphylococcus aureus, Bs-Bacillus subtilis, Ch- Chloramphenicol

Table 4. Bioactivity of crude extracts of $A$. flavus against fungal pathogen

\begin{tabular}{lcc}
\hline \multirow{2}{*}{ Solvents } & \multicolumn{2}{c}{ Zone of inhibition in mm } \\
\cline { 2 - 3 } & $\begin{array}{c}\mathrm{Ca} \\
1 \mathrm{mg} / \mathrm{ml}\end{array}$ & $\begin{array}{c}\mathrm{Fc} \\
1 \mathrm{mg} / \mathrm{ml}\end{array}$ \\
\hline Ethyl acetate & $19 \pm 0.5$ & $24 \pm 0.4$ \\
Methanol & $14 \pm 0.1$ & $22 \pm 0.7$ \\
Chloroform & $11 \pm 0.2$ & $21 \pm 0.2$ \\
\hline
\end{tabular}

The zone of inhibition of each extracts were expressed as the mean \pm standard deviation. Ca- Candida albicans, Fc- Fluconazole fermentation process, direct conversion of glucose to kojic acid without the formation of smaller fragments will occur. Among the groups of carbon sources glucose, fructose, sucrose, and lactose exhibit the maximum amount of kojic acid and dry mass by a mold A.flavus when compared to maltose, starch, cellulose, xylose, and arabinose. In agreement with this report various kojic acid synthesizing strains utilize glucose, sucrose, and fructose as a carbon source to obtain 0.5 to 0.6 $\mathrm{g}$ of kojic acid per $\mathrm{g}$ of glucose ${ }^{70}$. Hence glucose is considered as both precursors for kojic acid biosynthesis and mycelial growth ${ }^{69,70}$. 
Table 5. Effect of various carbon source on synthesis of kojic acid, drymass and consumption of sugar by A. flavus

\begin{tabular}{lccccc}
\hline $\begin{array}{l}\text { Carbon } \\
\text { source }\end{array}$ & $\begin{array}{c}\text { Kojic } \\
\text { acid } \\
\mathrm{g} / \mathrm{l}\end{array}$ & $\begin{array}{c}\text { Dry } \\
\text { weight } \\
\mathrm{g} / \mathrm{l}\end{array}$ & $\begin{array}{c}\text { Sugar } \\
\text { consumed } \\
\mathrm{g} / \mathrm{l}\end{array}$ & $\begin{array}{c}\text { Residual } \\
\text { sugar } \\
\mathrm{g} / \mathrm{l}\end{array}$ & $\begin{array}{c}\text { Kojic acid/ } \\
\text { sugar consumed } \\
\mathrm{g} / \mathrm{l}\end{array}$ \\
\hline Glucose & 30.1 & 8.2 & 60 & 40 & 0.5 \\
Sucrose & 28.3 & 8 & 72 & 28 & 0.39 \\
Fructose & 25.2 & 7.6 & 84 & 16 & 0.3 \\
Maltose & 17.1 & 2 & 0 & 100 & 0 \\
Lactose & 18.4 & 7.5 & 87 & 13 & 0.21 \\
Starch & 14.7 & 3 & 0 & 100 & 0 \\
Cellulose & 0 & 0 & 0 & 100 & 0 \\
Xylose & 0 & 0 & 0 & 100 & 0 \\
Arabinose & 0 & 0 & 0 & 100 & 0 \\
\hline
\end{tabular}

Among the various factors regulating the biosynthesis of kojic acid, the optimal source of nitrogen is a major component. The effect of nitrogen displayed in (Table 6) indicates that yeast extract, ammonium nitrate, and ammonium dihydrogen phosphate were the prominent nitrogen sources for manufacturing kojic acid (30.4, $24.3,15.6 \mathrm{~g} / \mathrm{I}$ respectively) with the consumption of glucose $(81,73,68 \mathrm{~g} / \mathrm{l}$ respectively) and the dry biomass were $(8.5,5.1,4.7 \mathrm{~g} / \mathrm{l}$ respectively). The increased amount was obtained when yeast extract was used as a source of nitrogen with consumed glucose $(81 \mathrm{~g} / \mathrm{l})$. Our results were parallel with reporters who explained that the immobilized cell cultures exhibit consumption of glucose and the progression of kojic acid synthesis was maximum and are proportional with the rise in nitrogen concentration but at increased concentration, production of kojic acid was reduced and consumption of glucose was highest $^{71}$.



Fig.3. Effect of various carbon source on synthesis of kojic acid drymass and consumption of sugar by $A$. flavus
Temperature plays a leading role in mycelial growth and kojic acid synthesis by potential A.flavus was appeared at $30^{\circ} \mathrm{C}(30.1 \mathrm{~g} / \mathrm{l})$ and dry biomass weight reached $(8.2 \mathrm{~g} / \mathrm{l})$. Some investigators showed that $25-30^{\circ} \mathrm{C}$ was the optimal temperature for the manufacturing of kojic acid by various fungi. ${ }^{71}$

Various ranges of $\mathrm{pH}$ were employed to achieve the greatest kojic acid and the highest level of mycelial growth by A.flavus. The potential fungi A.flavus showed better growth at $\mathrm{pH} 3$ to $5(7.5,8.4,7.1 \mathrm{~g} / \mathrm{l})$ on the contrary at $\mathrm{pH} 6$ to 8 the growth was completely reduced $(5.2,2,1$ $\mathrm{g} / \mathrm{l})$ while, biosynthesis of increased quantity of kojic acid $(31.5 \mathrm{~g} / \mathrm{l})$ was obtained with maximum consumption of glucose $(86 \mathrm{~g} / \mathrm{l})$ at $\mathrm{pH} 3$ however the amount of kojic acid was gradually decreased at $\mathrm{pH} \mathrm{s} 4,5,6$ and $\mathrm{pH} 7$ and 8 production was entirely nil as displayed in (Table 8 ). Our results are coinciding with the results ${ }^{72,28}$ reported that the strains, A. flavus, A. parasiticus, and $A$. oryzae exhibit optimum $\mathrm{pH}$ values $4.5,6.2,6.5$ for the secretion of kojic acid. Comparably, $A$. oryzae produces kojic acid at $\mathrm{pH} 4^{73}$, in contrast, the kojic acid values appeared in our investigation were not consistent with other reporters, in which the largest amount of kojic acid was obtained from glucose at very acidic $\mathrm{pH}(1.9 \text { to } 3.0)^{74}$. During growth progress at $\mathrm{pH} 4.5$ to 6 , the fungi use enzymes to convert glucose into kojic acid ${ }^{36}$. However, the growth of the fungi was continuous at $\mathrm{pH}$ between 2 and 3 the production of kojic acid appeared ${ }^{75}$. The change in the outcome of our vignette with the values of earlier results can 
Table 6. Effect of different nitrogen source on synthesis of kojic acid drymass and consumption of sugar by A.flavus

\begin{tabular}{lccccc}
\hline $\begin{array}{l}\text { Nitrogen } \\
\text { source }\end{array}$ & $\begin{array}{c}\text { Kojic } \\
\text { acid } \\
\mathrm{g} / \mathrm{l}\end{array}$ & $\begin{array}{c}\text { Dry } \\
\text { weight } \\
\mathrm{g} / \mathrm{l}\end{array}$ & $\begin{array}{c}\text { Glucose } \\
\text { consumed } \\
\mathrm{g} / \mathrm{l}\end{array}$ & $\begin{array}{c}\text { Residual } \\
\text { glucose } \\
\mathrm{g} / \mathrm{l}\end{array}$ & $\begin{array}{c}\text { Kojic acid/ } \\
\text { Glucose consumed } \\
\mathrm{g} / \mathrm{l}\end{array}$ \\
\hline An & 24.3 & 5.1 & 73 & 27 & 0.33 \\
Adp & 15.6 & 4.7 & 68 & 32 & 0.22 \\
Ye & 30.4 & 8.5 & 81 & 19 & 0.37 \\
Amhp & 10.3 & 4.2 & 58 & 42 & 0.17 \\
As & 7.1 & 4 & 79 & 21 & 0.08 \\
Sn & 0 & 0 & 0 & 100 & 0 \\
Pn & 1 & 0 & 0 & 100 & 0 \\
\hline
\end{tabular}

An-Ammonium nitrate, Adp- Ammonium dihydrogen phosphate, Ye- yeast extract, Amhp-Aammonium mono hydrogen phosphate,As- Asparagine, Sn- sodium nitrate, $\mathrm{Pn}$ - potassium nitrate

Table 7. Effect of incubation temperature on kojic acid production, drymass and consumption of sugar by A.flavus

\begin{tabular}{lccccc}
\hline $\begin{array}{l}\text { Temperature } \\
{ }^{\circ} \mathrm{C}\end{array}$ & $\begin{array}{c}\text { Kojic } \\
\text { acid } \\
\mathrm{g} / \mathrm{l}\end{array}$ & $\begin{array}{c}\text { Dry } \\
\text { weight } \\
\mathrm{g} / \mathrm{l}\end{array}$ & $\begin{array}{c}\text { Glucose } \\
\text { consumed } \\
\mathrm{g} / \mathrm{l}\end{array}$ & $\begin{array}{c}\text { Residual } \\
\text { glucose } \\
\mathrm{g} / \mathrm{l}\end{array}$ & $\begin{array}{c}\text { Kojic acid/ } \\
\text { Glucose consumed } \\
\mathrm{g} / \mathrm{l}\end{array}$ \\
\hline 15 & 10.2 & 2.3 & 54 & 46 & 0.18 \\
20 & 12.5 & 3.1 & 59 & 41 & 0.21 \\
25 & 26.1 & 5.6 & 74 & 26 & 0.35 \\
30 & 30.1 & 8.2 & 83 & 17 & 0.36 \\
35 & 20.6 & 4.5 & 78 & 22 & 0.26 \\
40 & 3 & 2.7 & 41 & 59 & 0.07 \\
45 & 0 & 1 & 0 & 100 & 0 \\
\hline
\end{tabular}

Table 8. Effect of pH on kojic acid synthesis, drymass and consumption of sugar by A. flavus

\begin{tabular}{cccccc}
\hline $\mathrm{pH}$ & $\begin{array}{c}\text { Kojic } \\
\text { acid } \\
\mathrm{g} / \mathrm{l}\end{array}$ & $\begin{array}{c}\text { Dry } \\
\text { weight } \\
\mathrm{g} / \mathrm{l}\end{array}$ & $\begin{array}{c}\text { Glucose } \\
\text { consumed } \\
\mathrm{g} / \mathrm{l}\end{array}$ & $\begin{array}{c}\text { Residual } \\
\text { glucose } \\
\mathrm{g} / \mathrm{l}\end{array}$ & $\begin{array}{c}\text { Kojic acid/ } \\
\text { Glucose consumed } \\
\mathrm{g} / \mathrm{l}\end{array}$ \\
\hline 2 & 19.8 & 4.2 & 75 & 25 & 0.26 \\
3 & 31.5 & 7.5 & 86 & 14 & 0.36 \\
4 & 27.2 & 8.4 & 78 & 22 & 0.34 \\
5 & 19.7 & 7.1 & 65 & 35 & 0.3 \\
6 & 9.5 & 5.2 & 48 & 52 & 0.19 \\
7 & 0 & 2 & 0 & 100 & 0 \\
8 & 0 & 1 & 0 & 100 & 0 \\
\hline
\end{tabular}

be described by the changes in the utilization of carbon and the nitrogen source. The most favorable $\mathrm{pH}$ for kojic acid is controlled by the kind of carbon and nitrogen source employed in the fermentation medium ${ }^{76}$.

Apart from Kojic acid various fungal isolates produce some other organic acids, according to some investigators, organic acids such as Malic acid (50.5M) from (Aspergillus flavus) ${ }^{77}$, Itaconic acid (87.32g/I )from (Aspergillus terreus) $^{78}$, Cyclopiazonic acid from (Aspergillus tamarii) $)^{79}$ and (Aspergillus flavus $)^{80}$ are obtained from several species of Aspergillus.

Besides, most of the plants are also notable for the production of various organic acids, for example, Tartaric, Citric, Malic, Lactic, 




Fig. 4. Effect of different nitrogen source on synthesis of kojic acid drymass and consumption of sugar by A.flavus

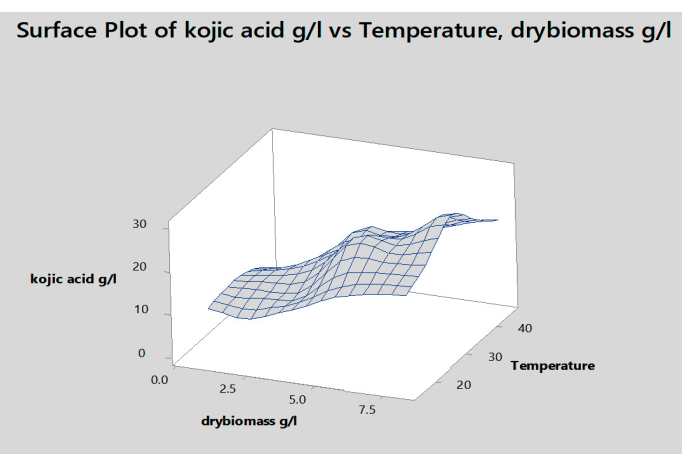

Fig. 5. Effect of incubation temperature on kojic acid production, drymass and consumption of sugar by A.flavus

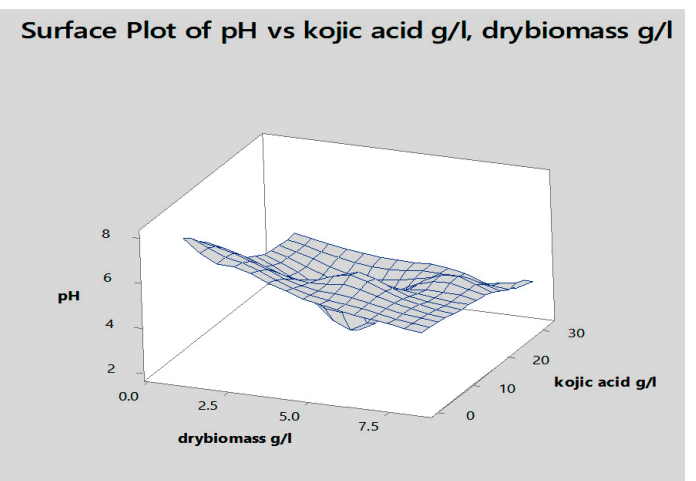

Fig. 6. Effect of pH on kojic acid synthesis, drymass and consumption of sugar by A.flavus

Succinic, Acetic, Oxalic acids ${ }^{81}$, some Malus species generously incorporated malic acid and citric $\operatorname{acid}^{82}$, there are no shreds of evidence for kojic acid production from plants.

\section{CONCLUSION}

The present investigation was focused to optimize cultural conditions to synthesize maximum kojic acid from A.flavus. Glucose and yeast extract were the optimal carbon and nitrogen sources. Kojic acid can be obtained by employing other carbon sources like sucrose, fructose, and lactose. The optimum incubation temperature was $30^{\circ} \mathrm{C}$ and $\mathrm{pH} 3(31.5 \mathrm{~g} / \mathrm{l})$. Hence, in the present work, authors attribute kojic acid production from marine Aspergillus flavus, and compared to other acids, Kojic acid achieved from Aspergillus species has wide applications in various fields. Additionally, further investigation is needed to boost human power to fight with various microbial diseases.

\section{ACKNOWLEDGMENTS}

We wish to thank Microbial Type Culture Collection and Gene Bank (MTCC), is funded by the Department of Biotechnology (DBT) and the Council of Science and Industrial Research (CSIR), Government of India, for providing different strains. We would like to express sincere thanks P.G Department of studies in Biotechnology and Microbiology, Karnataka University, Dharwad, Karnataka for providing facilities.

\section{CONFLICTS OF INTEREST}

conflict of interest.

The authors declare that there is no

\section{FUNDING}

None.

\section{AUTHOR'S CONTRIBUTION}

All authors listed have made a substantial, direct and intellectual contribution to the work, and approved it for publication.

\section{DATA AVAILABILITY}

All the data accomplished in the time of this research are incorporated in the manuscript.

\section{ETHICS STATEMENT}

This article does not contain any studies with human participants or animals performed by any of the authors.

\section{REFERENCES}

1. Faulkner D.J. Marine pharmacology. Antonie Van Leeuwenhoek, 2000; 77: 135-145. https://doi. org/10.1023/A:1002405815493

2. Saleem M., Ali M.S., Hussain S., Jabbar A., Ashraf M., Lee Y.S. Marine natural products of fungal origin. Nat Prod Rep., 2007; 24: 1142-1152. https:// doi.org/10.1039/b607254m 
3. Bugni T.S., Ireland C.M. Marine-derived fungi: a chemically and biologically diverse group of microorganisms. Nat. Prod. Rep., 2004; 21: 143-163. https://doi.org/10.1039/b301926h

4. Gootz T.D. The global problem of antibiotic resistance. Crit. Rev. Immunol., 2010; 30: 79-93. https://doi. org/10.1615/CritRevlmmunol.v30.i1.60

5. Courvalin P. Predictable and unpredictable evolution of antibiotic resistance. J. Intern. Med., 2008; 264: 4-16. https://doi.org/10.1111/j.1365-2796.2008.01940.x

6. Martinez J.L., Fajardo A., Garmendia L., Hernandez A., Linares J.F., Martinez-Solara L. A global view of antibiotic resistence. FEMS, 2008; 33: 44-65. https:// doi.org/10.1111/j.1574-6976.2008.00142.x

7. Styers D., Sheetian D. J., Hogan P., Sahm D. F. Laboratory based surveillance of current antimicrobial resistance pattern and trends among S. aureus, Ann. Clin. Microb. Antimicrob, 2006; 5: 2. https://doi.org/10.1186/14760711-5-2

8. Adegoke, Anthony Ayodeji, Komolafe, Amos, Omoniyi. Nasal Colonization of School Children in Ile-Ife by Multiple Antibiotic Resistant Staphylococcus aureus. International Journal of Biotechnology and Allied Sciences, 2008; 3: 317-322.

9. Adegoke, Anthony Ayodeji, Komolafe, Amos Omoniyi. Multidrug Resistant Staphylococcus aureus in Clinical Cases in Ile-Ife, Southwest Nigeria. International Journal of Medicine and Medical Sciences, 2009; 1: 068-072.

10. Komolafe A.O., Adegoke A.A. Incidence of bacterial septicemia in Ile-Ife Metropolis, Nigeria. Malaysian Journal of Microbiology, 2008a; 4: 51-61. https://doi. org $/ 10.21161 / \mathrm{mjm} .13008$

11. Hazra B., Biwas S., Mandal. Antioxidant and free radical scavenging activity of Spondias pinnata. BMC Complement Altern Med., 2008; 8: 63 (doi: 10.1186/1472-6882-8-63). https://doi. org/10.1186/1472-6882-8-63

12. Hala Ammar A. M., Saeid Ezzat M., Asmaa Houseny M. Improved production of kojic acid by mutagenesis of Aspergillus flavus HAk1 and Aspergillus oryzae HAk2 and their potential antioxidant activity. 3 Biotech., 2017; 7: 276. https://doi.org/10.1007/s13205-0170905-4

13. Abd El-Aziz B.A. Improvement of kojic acid production by a mutant strain of Aspergillus flavus. J. Nat. Sci. Res., 2013; 3: 31-41.

14. Marina Della Greca, Gaetano De Tommaso, Maria Michela Salvatore, Rosario Nicoletti, Andrea Becchimanzi, Mauro Iuliano, Anna Andolfi. The Issue of Misidentification of Kojic Acid with Flufuran in Aspergillus flavus Molecules. 2019; 24: 1709. https:// doi.org/10.3390/molecules24091709

15. Chambergo F.S., Valencia E.Y. Fungal biodiversity to biotechnology. Appl. Microbiol. Biotechnol., 2016; 100: 2567-2577. https://doi.org/10.1007/s00253016-7305-2

16. Meyer V., Andersen M.R., Brakhage A.A., Braus G.H., Caddick M.X., Cairns T.C., de Vries R.P., Haarmann T., Hansen K., Hertz-Fowler C., et al. Current challenges of research on filamentous fungi in relation to human welfare and a sustainable bio-economy. A white paper. Fungal Biol. Biotechnol., 2016; 3: 6. https://doi. org/10.1186/s40694-016-0024-8

17. Nicoletti R., Salvatore M.M., Andolfi A. Secondary metabolites of mangrove-associated strains of Talaromyces. Mar. Drugs, 2018; 16: 12. https://doi. org/10.3390/md16010012

18. Felix C., Salvatore M.M., Della Greca M., Meneses R., Duarte A.S., Salvatore F., Naviglio D., Gallo M., Jorrino-Novo J.V., Alves A., et al. Production of toxic metabolites by two strains of Lasiodiplodia theobromae, isolated from a coconut tree and a human patient. Mycologia, 2018; 110: 642-653. https://doi. org/10.1080/00275514.2018.1478597

19. Marra R., Nicoletti R., Pagano E., Della Greca M., Salvatore M.M., Borrelli F., Lombardi N., Vinale F., Woo S.L., Andolfi A. Inhibitory effect of trichodermanone C, a sorbicillinoid produced by Trichoderma citrinoviride associated to the green alga Cladophora sp., on nitrite production in LPS-stimulated macrophages. Nat. Prod. Res., 2018. https://doi.org/10.1080/14786419.2018.1 479702

20. Zhao J., Shan T., Mou Y., Zhou L. Plant-Derived Bioactive Compounds Produced by Endophytic Fungi. Mini-Rev. Med. Chem., 2011; 11: 159-168. https://doi.org/10.2 174/138955711794519492

21. Pillaiyar T., Namasivayam V., Manickam M., Jung S.H. Inhibitors of Melanogenesis: An Updated Review. J. Med. Chem., 2018; 61: 7395-7418. https://doi. org/10.1021/acs.jmedchem.7b00967

22. Saeedi M., Eslamifar M., Khezri K. Kojic acid applications in cosmetic and pharmaceutical preparations. Biomed. Pharm., 2019; 110: 582-593. https://doi. org/10.1016/j.biopha.2018.12.006

23. Brtko J., Rondahl L., Fickova M., Hudecova D., Eybl V., Uher M. Kojic acid and its derivatives: history and present state of art. Cent. Eur. J. Public Health, 2004; 12: $16-18$

24. Lee Y.S., Park J.H., Kim M.H., Seo S.H., Kim H.J. Syntheisis of tyrosinase inhibitory kojic acid derivative. Archiv. Pharm., 2006; 339: 111-114. https://doi. org/10.1002/ardp.200500213

25. Khamaruddin N.R., Basri M., Lian G.E.C., Salleh A.B., Rahman R.N.Z., Ariff A.B., Mohamad R., Awang R. Enzymatic synthesis and characterization of palmbased kojic acid ester. J. Oil Palm Res., 2008; 20: 461469.

26. Ashari S.E., Mohamad S., Ariff A., Basri M., Salleh A.B. Optimization of enzymatic synthesis of palm-based kojic acid ester using response surface methodology. J. Oleo. Sci., 2009; 58: 503-510. https://doi.org/10.5650/ jos.58.503

27. Della Greca M., De Tommaso G., Salvatore M.M., Nicoletti R., Becchimanzi A., luliano M., Andolfi A. The Issue of Misidentification of Kojic Acid with Flufuran in Aspergillus flavus. Molecules, 2019; 24: 1709. https:// doi.org/10.3390/molecules24091709

28. Hazzaa M.M., Saad A.M., Hassan H.M., Ibrahim E. High Production of Kojic acid crystals by isolated Aspergillus oryzae var. effuses NRC14. J. Appl. Sci. Res., 2013; 9 : 1714 - 1723.

29. Bentley R. From miso, sake and shoyu to cosmetics: a century of science for kojic acid. Nat. Prod. Rep., 2006; 
23: 1046-1062. https://doi.org/10.1039/b603758p

30. Arnstein H.R.V., Bentley R. The biosynthesis of kojic acid 2. The occurrence of aldolase and trioephosphate isomerase in Aspergillus species and their relationship to kojic acid biosynthesis. Biochem. J., 1953b; 5: 508516. https://doi.org/10.1042/bj0540508

31. Le Blanch D.T., Akers H.A. Maltol and ethyl maltol from larch tree to successful food additives. Food Technol., 1989; 26: 78-87.

32. Chen J.S., C. Wei., M.R. Marshall., Inhibition mechanism of kojic acid on polyphenol oxidase. J. Agric. Food Chem., 1991; 39: 1897-1901. https://doi.org/10.1021/ jf00011a001

33. Ohyama Y., Mishima Y. Melanosis-inhibitory effect of kojic acid and its action mechanism. Fragrance J., 1990; 6: 53-58.

34. Buchta K. Organic acids of minor importance. In Rehm HJ, Reed G, H Dellweg H (eds.) Biotechnology: A Comprehensive Treaties Vol. 3: Biomass, Microorganisms for Special Applications, Microbial Products, Energy from Renewable Resources. Ingelheim: Federal Republic of Germany 1982.

35. Dowd P.F. Toxicological and biochemical interactions of the fungal metabolites fusaric acid and kojic acid with xenobiotics in Heliothis zea (F.) and Spodoptera frugiperda (J.E. Smith). Pestic. Biochem. Physiol., 1988; 32: 123-134. https://doi.org/10.1016/00483575(88)90005-3

36. Rosfarizan M., Ariff A.B., Hassan M.A., Karim M.I.A. Influence of $\mathrm{pH}$ on Kojic Acid Fermentation by Aspergillus flavus. Pakistan Journal of Biological Sciences., 2000; 3: 977-988. https://doi.org/10.3923/ pjbs.2000.977.982

37. White T.J., Bruns T., Lee S., Taylor J.W. Amplification and direct sequencing of fungal ribosomal RNA genes for phylogenetics. Pp. 315-322 In: PCR Protocols: A Guide to Methods and Applications, eds. Innis, M. A., D.H. Gelfand, J.J. Sninsky, and T.J. White. Academic Press, Inc., New York 1990. https://doi.org/10.1016/B978-012-372180-8.50042-1

38. Darby A.C., Chandler S.M., Welburn S.C., Douglas A.E. Aphid-symbiotic bacteria cultured in insect cell lines. Appl. Environ. Microbiol., 2005; 71: 4833-4839. https://doi.org/10.1128/AEM.71.8.4833-4839.2005

39. Altschul S.F., Gish W., Miller W., Myers E.W., Lipman D.J. Basic local alignment search tool. J Mol. Biol., 1990; 215: 403-10. https://doi.org/10.1016/S00222836(05)80360-2

40. Gertz E.M. BLAST Scoring Parameters, 16 March 2005

41. States D.J., Gish W., Altschul S.F. "Improved sensitivity of nucleic acid database searches using applicationspecific scoring matrices." Methods, 1991; 3: 66-70. https://doi.org/10.1016/S1046-2023(05)80165-3

42. Barnard D., Challenger F. The formation of kojic acid from ethyl alcohol by Aspergillus oryzae, and the action of this mould on some carbohydrate derivatives. J. Chem. Soc., 1949: 110-117. https://doi.org/10.1039/ JR9490000110

43. Miller G.L. Use of dinitrosalicylic acid reagent for determination of reducing sugar. Analytical Chemistry, 1959; 31: 426-428. https://doi.org/10.1021/ ac60147a030
44. Bentley R. Preparation and analysis of kojic acid. Methods Enzymol., 1957; 3: 238-241. https://doi. org/10.1016/S0076-6879(57)03381-9

45. Barry A.L., Brown S.D. Fluconazole disk diffusion procedure for determining susceptibility of Candida species. J. Clin. Microbiol., 1996; 34: 2154-2157.

46. Mohamad R.S., Madihah, Ariff A.B. Isolation of a kojic acid producing fungus capable of using starches as a carbon source. Lett. Appl. Microbiol. 1998; 26: 27-30. https://doi.org/10.1046/j.1472-765X.1998.00263.x

47. El-Aziz A.B.A. Improvement of kojic acid production by a mutant strain of Aspergillus flavus. Journal of Natural Sciences Research, 2013; 3: 31-41.

48. Arnstein H.R.V., Bentley R. The biosynthesis of kojic acid: the incorporation of labeled small molecules into kojic acid. Biochemistry. 1953; 54: 517-522. https:// doi.org/10.1042/bj0540517

49. Basappa S.C., Sreenivasamurthy V., Parpia H.A. Matoxin and kojic acid production by resting cells of Aspergillus flavus link. Journal of General Microbiology. 1970; 61: 81- 86. https://doi.org/10.1099/00221287-61-1-81

50. Ariff A.B., Salleh M.S., Ghani B., Hassan M.S., Rusul G., Karim M.I.A. Aeration and yeast extract requirements for kojic acid production by Aspergillus flavus Link. Enzyme Microbiol. Technol., 1996; 19: 545-550. https://doi.org/10.1016/\$0141-0229(96)00065-8

51. El-Aasar S.A. Cultural conditions studies on kojic acid production by Aspergillus parasiticus. Inter. J. Agri. Biol., 2006; 8: 468 - 473.

52. May O.E., Moyer A.J.,Wells P.A., Herbik H. The production of kojic acid by Aspergillus flavus. J. Am. Chem. Soc., 1931; 53: 774 -782. https://doi. org/10.1021/ja01353a050

53. Futamura T., Okabe M., Tamura T., Toda K., Matsunobu T., Park Y.S. Improvement of production of kojic acid by a mutant strain Aspergillus oryzae, MK 107-39. J. Biosci. Bioeng., 2001; 91: 272 - 276. https://doi.org/10.1263/ jbb.91.272

54. Ogawa A., Morita Y., Tanaka T., Sakiyama T., Nakanishi K. Production of kojic acid from Aspergillus oryzae var.oryzae by membrane-surface liquid culture. Biotechnol. Tech., 1995; 9: 153 - 156. https://doi. org/10.1007/BF00224417

55. Saad A.M., Hamed H., Saad M.M. Kojic acid production by a toxigenic strain of Aspergillus paraiticus and a non-toxigenic strain of Aspergillus flavus. Afr. J. Mycol. Biotechnol., 1996; 4: 19 - 27.

56. Gad A.S. Modification of molasses for kojic acid production by Aspergillus parasiticus. New Egypt. J. Microbiol., 2003; 5: 14 - 26.

57. El-kady I.A., Zohri A.A., Ragab S.H. Kojic acid production from agro-industrial by-products using fungi. Biotechnol Res Int., 2014. https://doi. org/10.1155/2014/642385

58. Moharram A.M., Zohri A.A., Seddek N.H. Production of kojic acid by endophytic fungi isolated from medicinal plant in Egypt. Int Invent J Biochem Bioinf., 2015; 3: 28-31.

59. Megalla S.E., Bennett G.A., Ellis J.J., Shotell O.I. Production of deoxynivalenol and zearalenone by isolates of Fusarium graminearum SCHW. J. Basic Microbiol., 1986; 26: 415-419. https://doi. 
org/10.1002/jobm.3620260709

60. Parrish F.W., Wiley B.J., Simmons E.G., Long L. Production of aflatoxins and kojic acid by species of Aspergillus and Penicillium. Appl Microbiol. 1966; 14: 139.

61. Manabe M., Tanaka K., Goto T., Matsura S. Producing capability of colic acid and aflatoxin by mould. Develop Food Sci., 1984; 7: 4-14.

62. Megalla S.E., Nassar A.Y., Gohar M.A. The role of copper (I)-nicotinic acid complex on kojic acid biosynthesis by Aspergillus flavus. J. Basic Microbiol., 1987; 27: 29-33. https://doi.org/10.1002/jobm.3620270105

63. Kharchenko S.N., latsyshin A.I., Tea E.M., Pototski N.K., Pavlenko I. The species composition of the micromycetes in feed and their role in animal kojic acid toxicosis. Mikrobiologicheskii Zhurnal., 1993; 55: 78-84.

64. El-Sharkawy S.H. Kojic acid production from cocoa juice by Aspergillus flavus entrapped in calcium alginate. Boll Chim Farmac., 1995; 134: 316-319.

65. Ariff A.B., Rosfarizan M., Herng L.S., Madihah S., Karim M.I.A. "Kinetics and modelling of kojic acid production by Aspergillus flavus link in batch fermentation and resuspended mycelial system," World Journal of Microbiology and Biotechnology, 1997; 13: 195-201. https://doi.org/10.1023/A:1018593815266

66. Rosfarizan M., Ariff A.B. "Kinetics of kojic acid fermentation by Aspergillus flavus using different types and concentrations of carbon and nitrogen sources." Journal of Industrial Microbiology and Biotechnology, 2000; 25: 20-24. https://doi. org/10.1038/sj.jim.7000017

67. Ogawa A., Wakisaka, Tanaka T., Sakiyama T., Nakanishi K. "Production of kojic acid by membrane-surface liquid culture of Aspergillus oryzae NRRL484." Journal of Fermentation and Bioengineering, 1995; 80: 41-45. https://doi.org/10.1016/0922-338X(95)98174-J

68. Wakisaka Y., Segawa T., Imamura K., Sakiyama T., Nakanishi K. "Development of a cylindrical apparatus for membrane-surface liquid culture and production of kojic acid using Aspergillus oryzae NRRL484." Journal of Fermentation and Bioengineering, 1998; 85: 488-494. https://doi.org/10.1016/S0922-338X(98)80067-6

69. Kitada M., Ueyama H., Fukimbara T. Studies on kojic acid fermentation. (I) Cultural condition in submerged culture. J Ferment Technol., 1967; 45: 1101-1107.

70. Kwak M.Y., Rhee J.S. Control mycelial growth for kojic acid production using ca-alginate immobilized fungal cells. Appl. Microbiol. Biotechnol., 1992; 36: 578-583. https://doi.org/10.1007/BF00183232

71. Lin M.T., Mahojan J.R., Dianese J.C., Takatsu A.
High production of kojic acid crystals by Aspergillus parasiticus UNBF A12 in liquid medium. Appl. Environ. Microbiol., 1976; 32: 298-299.

72. Lin C.C. The effect of equipping a non-waven fabrics in the fermenter on the production of kojic acid by Aspergillus flavus. M.Sc. Thesis, Chemical Engineering, China, 2001.

73. Clevstrom G., H. Ljunggren. Aflatoxin formation and the dual phenomenon in Aspergillus flavus Link. Mycopathol., 1985; 92: 129-139. https://doi. org/10.1007/BF00437624

74. Rosfarizan M., A. Ariff. Importance of carbon source feeding and $\mathrm{pH}$ control strategies for maximum kojic acid production from sago starch by Aspergillus flavus. J Biosci Bioeng., 2002; 94: 99-105. https://doi. org $/ 10.1263 / \mathrm{jbb} .94 .99$

75. Rosfarizan M., Mohd Shamzi M., Nurashikin S., Salleh M. M., Arbakariya Ariff B. Kojic acid: Applications and development of fermentation process for production. Biotechnol Molecular Biology Reviews, 2010; 5: 24-37.

76. Wood B.J.B. Microbiology of Fermented Food (2 ${ }^{\text {nd }}$ Edition), Springer, London 1998.

77. Yoav peleg., Barry Stieglitz, Israel Goldberg. Malic acid accumulation by Aspergillus flavus Appl. Microbial Biotechnol., 1988; 28: 69-75. https://doi.org/10.1007/ BF00250501

78. Peter Komaromy., Peter Bakonyi, Adrienn Kucska., Gabor Toth., Laszlo Gubicza., Katalin Belafi-Bako., Nandor Nemestothy. Optimized pH and Its Control Strategy Lead to Enhanced Itaconic Acid Fermentation by Aspergillus terreus on Glucose Substrate. Fermentation, 2019; 5: 31. https://doi.org/10.3390/ fermentation 5020031

79. Joe dorner W. Production of Cyclopiazonic Acid by Aspergillus tamarii Kita. Applied and Environmental Microbiology, 1983; 46: 1435-1437.

80. Luk K.C., Kobbe B., Townsend J.M. Production of Cyclopiazonic Acid by Aspergillus flavus Link. Applied and Environmental Microbiology, 1977; 33: 211-212.

81. Joanna Chlopicka., Justyna Dobrowolska-Iwanek., Michal Wozniakiewicz, Pawel Zagrodzki. Optimization of Conditions for Organic Acid Extraction from Edible Plant Material as Applied to Radish Sprouts. Food Anal. Methods 2014; 7: 1323-1327. https://doi. org/10.1007/s12161-013-9752-z

82. Baiquan Ma, Yangyang Yuan, Meng Gao, Cuiying Li, Collins Ogutu, Mingjun Li, Fengwang Ma. Determination of Predominant Organic Acid Components in Malus Species: Correlation with Apple Domestication. Metabolites 2018; 8: 74. https://doi.org/10.3390/ metabo8040074. 